\title{
Think Hickam's Dictum not Occam's Razor in paediatric HIV
}

\author{
Felicity Goodyear-Smith, ${ }^{1}$ Mike Sharland ${ }^{2}$ Simon Nadel ${ }^{3}$
}

${ }^{1}$ General Practice and Primary Health Care, University of Auckland, Auckland,

New Zealand

${ }^{2}$ Paediatric Infectious Diseases,

St. George's Hospital,

University of London, London, UK

${ }^{3}$ Paediatric Infectious Diseases, St Mary's Hospital, London, UK

\section{Correspondence to}

Professor Felicity GoodyearSmith, f.goodyear-smith@ auckland.ac.nz

Accepted 1 March 2014
CrossMark

To cite: Goodyear-Smith $F_{\text {, }}$ Sharland M, Nadel S. BMJ Case Rep Published online: [please include Day Month Yearl doi:10.1136/bcr-2013202029

\section{SUMMARY}

A 10-year-old girl with untreated congenital HIV developed acute sepsis to which she succumbed despite emergency treatment. Her red and dilated anal region with small areas of tissue breakdown due to advanced HIV destructive disease was misinterpreted as anal assault. Suffocation was then hypothesised to be the cause of her profound hypoxia and multi-organ failure. Criminal proceedings against her adoptive uncle ensued over a 5-year period at huge legal and social cost. Following the first acquittal, appellant hearings led to re-trial at which her uncle was acquitted for the second time. A shared idée fixe (anal assault and asphyxiation) resulted in the most likely clinical diagnosis (advanced HIV infection with subsequent overwhelming sepsis) being discarded. This was a case where the principle of parsimony (Occam's Razor) led to exclusion of a diagnosis when in fact multiple diagnoses applied (Hickam's Dictum), with devastating consequences for the family.

\section{BACKGROUND}

This case demonstrates how a shared idée fixe resulted in the most likely clinical diagnosis being discarded, with huge personal costs for a child's family and financial costs for the state.

\section{CASE PRESENTATION}

In 2007, a 10-year-old girl, an immigrant to New Zealand from Zimbabwe, was found by her adoptive aunt in bed, deeply unconscious, gasping for breath and lying in a pool of diarrhoea. On transfer to accident and emergency at the local hospital, she was found to have a Glasgow Coma Score of 3, tachycardia (HR 183), no recordable blood pressure, pyrexia $\left(40.3^{\circ} \mathrm{C}\right)$, tachypnoea (35), widespread pulmonary crepitations and mottled limbs. Her capillary refill time was $6 \mathrm{~s}$, reducing to $3 \mathrm{~s}$ following fluid resuscitation. Her blood pressure was maintained at around 70/40 once intravenous fluids and inotropic drugs were administered. Upon transfer to intensive care, a prolapsed and unusually inflamed rectal mucosa was interpreted as a $7 \mathrm{~cm}$ rectal tear. The clinical team diagnosed sepsis secondary to a perforated bowel secondary to rectal sexual assault. Her sepsis then was hypothesised as due to a perforated bowel from anal sexual assault. Proctoscopic examination by a paediatric surgeon revealed no rectal laceration, but multiple $1-3 \mathrm{~mm}$ mucosal splits were seen occurring radially around her anal margin. The clinicians in charge of her care continued to believe there was a large rectal wound, and speculated that her hypoxic state was the result of asphyxia in the context of anal rape.

\section{INVESTIGATIONS}

Arterial blood gas analysis

Transcutaneous oxygen saturation initially 91\%, increased to $93 \%$ when oxygen was given by mask, and reached $100 \%$ following intubation. Initial venous $\mathrm{pH} 7.05, \mathrm{HCO}_{3} 8.6$ (metabolic acidosis).

\section{Haematology}

INR 2.5 (0.8-1.2), APTT 58 s (26-36), thrombin clotting time $28 \mathrm{~s}$ (18-25), platelet count 140 (150-450), haemoglobin 94 (115-140), haematocrit $0.29(0.34-0.44)$, white cell count 12.5 , neutrophils 4.4, lymphocytes 7.6 (1.5-7), monocytes 0.37 , myelocytes $0.03(0)$. Neutrophils showed toxic granulation with Döhle bodies present, irregular shaped cells + , Rouleau ++ .

\section{Biochemistry}

Sodium 142, potassium 3.5, urea 9.7 (3.5-5), creatinine 0.19 (0.03-0.09), bilirubin 5, ALP 123, GGT 91 (5-30), AST 227 (10-50), ALT 65 (<30), CRP $48(<5)$.

\section{Microbiology}

HIV screening assay and Western blot positive. Vaginal swab grew Staphylococcus aureus. Single blood culture taken subsequent to administration of intravenous antibiotics was negative. No lumbar puncture was done.

\section{Radiology}

Chest X-ray showed consolidation in right lower lobe and both upper lobes. Abdominal X-ray normal (ruled out perforation). CT scan head showed diffuse decreased attenuation in the white matter of both frontal lobes and temporal lobes, basal ganglia and thalmi bilaterally. Bilateral otitis media and sinusitis. CT scan abdomen showed a "diffuse "shock bowel" appearance in the large and small bowel, consistent from changes from hypovolaemic septic shock'.

\section{TREATMENT}

Despite immediate resuscitation plus intravenous antibiotics, anti-viral and anti-fungal agents, the child failed to respond and died $19 \mathrm{~h}$ after first presenting.

\section{DIFFERENTIAL DIAGNOSIS}

Initially the girl was assumed to have an overwhelming sepsis in the context of advanced HIV disease. However, once the anal region was visualised, the hypoxia was diagnosed to be secondary to presumed asphyxiation with anal trauma from 
assault. The more common diagnosis of hypoxia secondary to acute respiratory distress syndrome and multi-organ failure due to septic/toxic shock was excluded. Her positive HIV status was considered not to be relevant by those involved in her care. It was claimed in court that her hypoxia could not be due to lung pathology because her oxygen saturation levels improved following administration of oxygen, and neither could it be due to hypovolaemic septic shock because she had failed to improve after being given a second bolus of intravenous fluid and remained anuric, and furthermore neither of these options explained the rectal trauma, hence the hypoxia could only be the result of suffocation.

Subsequent international expert review of the case and pathology indicates that this child had advanced AIDS with severe chronic HIV-destructive encephalitis, pneumonitis and pan-enteritis. It was considered most probable that the child succumbed to acute sepsis, possibly due to toxic shock from $S$ aureus infection. The child fulfilled the clinical criteria for toxic shock syndrome.

\section{OUTCOME AND FOLLOW-UP}

The child's parents had both died in Zimbabwe with 'immune deficiency' when she was a baby, and it became apparent she had congenital HIV infection which had never been treated.

Prior to her death the police and the forensic pathologist were notified that this was a case of rape and murder. The police attended the hospital and began interviewing family members (her aunt and uncle who were her adoptive parents and their biological children who were young adults). The child's biological sister aged 12 (who later tested negative for HIV) was immediately taken into care. Her uncle was arrested and charged with homicide and sexual violation. There followed a number of hearings: depositions (2007), a High Court trial (2008) resulting in acquittal, a Family Court hearing (2009) deciding that the older sister must remain in care, prosecution appeal to the Court of Appeal (2009) dismissed, prosecution appeal to the Supreme Court (2010) upheld and re-trial ordered.

The full story unfolded when the medical adviser for the defence (FG-S) pieced together chronologically the many facts pertaining to the case and obtained an overview of the events which had culminated in the girl's demise.

For the retrial the defence called four experts from the UK: a paediatrician experienced in infectious diseases and HIV (MS), a paediatric intensivist (SN), a histopathologist with extensive HIV expertise (Professor Sebastian Lucas) and a Home Office forensic pathologist (Dr Nathaniel Cary). MS and SN explained how this case had all the hallmarks of overwhelming sepsis presenting in an immune-suppressed child. Having reviewed the case by preparing numerous additional slides using immunochemical stains, Professor Lucas concluded that this was the most severe case of tissue damage due to HIV that he had ever seen in a child. The High Court retrial (2012) resulted in a second acquittal.

Following the second acquittal, a Family Court judge lifted the restraining order preventing the deceased's older sister (then 17) having contact with her adopted father. ${ }^{1}$

\section{DISCUSSION}

The aetiological agent is often not identified in acute sepsis. ${ }^{2}$ Combination antiretroviral therapy has markedly reduced mortality in children with perinatally acquired HIV, and therefore few clinicians now have experience with this condition. ${ }^{3}$ In nonclassical presentations, an underlying immune deficiency always should be considered. In this case, senior clinicians apparently developed an idée fixe with respect to the diagnosis (anal rape and asphyxia, mistakenly identifying rectal trauma and refusing to accept that even on histological examination a large tear was not present) and rejected the possibility that HIV might play an important part in the girl's acute presentation. This meant that it became increasingly difficult for more junior staff to consider alternative possibilities, possibly inadvertently colouring their perceptions and subsequent recall, and resulting in a team belief that the child had been a victim of assault. In a complex case where many people are involved in the acute care with prescribed roles, the story may subtly change when transmitted from one person to another. For example, the child presented with profuse strange-coloured watery diarrhoea, which drenched her clothes and bedding. A nurse inserting two suppositories of a paracetamol in the after-hours clinic had noted a smear of blood on her gloved finger. The hospital Record of Death stated that the child had been admitted with 'rectal bleeding', but there was no mention of diarrhoea or of her HIV status. Arranging for an external review of the whole case to be conducted may be very valuable so that the big picture can be seen.

Factors strongly suggesting infection (such as high pyrexia, profuse diarrhoea, haematological findings) were forced to fit with the rape and murder scenario. Sepsis was excluded as a possibility because it did not explain the presumed rectal injuries. This is an example of the inappropriate use of Occam's Razor parsimony principle, which advocates reduction to a single hypothesis. In fact, this appeared to be more a case of Hickam's Dictum, with a multifactorial pathogenesis combining direct HIV organ damage, immune deficiency and an overwhelming inflammatory response to sepsis.

\section{Learning points}

- Consider the possibility of immune deficiency in acute atypical presentations

- Seek expert advice, internationally if necessary, when a case is outside one's usual clinical experience, especially where there are serious ramifications.

- Consider all possible diagnoses and keep revisiting discarded ones if subsequent evidence fails to fit the assumed diagnosis.

- When senior clinicians present an idée fixe with respect to a diagnosis, it becomes increasingly difficult for more junior staff to consider alternative possibilities.

- The principle of parsimony (Occam's Razor) may sometimes lead to exclusion of a diagnosis when in fact multiple diagnoses may apply (Hickam's Dictum).

Acknowledgements To the family for the dignified way they conducted themselves throughout this 5-year ordeal.

Contributors All three authors have made individual contributions to the writing of the article in regard to its conception and design, drafting or revising it critically for important intellectual content and have given final approval of the version to be published.

Competing interests None.

Patient consent Obtained. 
Provenance and peer review Not commissioned; externally peer reviewed.

\section{REFERENCES}

1 Radio NZ. Restraining order lifted. 7 November 2012. http://www.radionz.co.nz/news/ national/120188/restraining-order-lifted
2 Nadel S, Goldstein B, Williams MD, et al. Drotrecogin alfa (activated) in children with severe sepsis: a multicentre phase III randomised controlled trial. Lancet 2007;369:836-43.

3 Gortmaker SL, Hughes M, Cervia J, et al. Effect of combination therapy including protease inhibitors on mortality among children and adolescents infected with HIV-1. N Engl J Med 2001;345:1522-8.

Copyright 2014 BMJ Publishing Group. All rights reserved. For permission to reuse any of this content visit

http://group.bmj.com/group/rights-licensing/permissions.

BMJ Case Report Fellows may re-use this article for personal use and teaching without any further permission.

Become a Fellow of BMJ Case Reports today and you can:

- Submit as many cases as you like

- Enjoy fast sympathetic peer review and rapid publication of accepted articles

- Access all the published articles

- Re-use any of the published material for personal use and teaching without further permission

For information on Institutional Fellowships contact consortiasales@bmjgroup.com

Visit casereports.bmj.com for more articles like this and to become a Fellow 